\title{
Bacillus sp. CSK2 produced thermostable alkaline keratinase using agro-wastes: keratinolytic enzyme characterization
}

\author{
Nonso E. Nnolim ${ }^{1,2}$ and Uchechukwu U. Nwodo ${ }^{1,2^{*}}$
}

\begin{abstract}
Background: Chicken feathers are the most abundant agro-wastes emanating from the poultry processing farms and present major concerns to environmentalists. Bioutilization of intractable feather wastes for the production of critical proteolytic enzymes is highly attractive from both ecological and biotechnological perspectives. Consequently, physicochemical conditions influencing keratinase production by Bacillus sp. CSK2 on chicken feathers formulation was optimized, and the keratinase was characterized.

Results: The highest enzyme activity of $1539.09 \pm 68.14 \mathrm{U} / \mathrm{mL}$ was obtained after $48 \mathrm{~h}$ of incubation with optimized conditions consisting of chicken feathers $(7.5 \mathrm{~g} / \mathrm{L})$, maltose $(2.0 \mathrm{~g} / \mathrm{L})$, initial fermentation $\mathrm{pH}(5.0)$, incubation temperature $\left(30^{\circ} \mathrm{C}\right)$, and agitation speed $(200 \mathrm{rpm})$. The keratinase showed optimal catalytic efficiency at pH 8.0 and a temperature range of $60^{\circ} \mathrm{C}-80^{\circ} \mathrm{C}$. The keratinase thermostability was remarkable with a half-life of above 120 min at $70^{\circ} \mathrm{C}$. Keratinase catalytic efficiency was halted by ethylenediaminetetraacetic acid and 1,10-phenanthroline. However, keratinase activity was enhanced by 2-mercaptoethanol, dimethyl sulfoxide, tween-80, but was strongly inhibited by $\mathrm{Al}^{3+}$ and $\mathrm{Fe}^{3+}$. Upon treatment with laundry detergents, the following keratinase residual activities were achieved: $85.19 \pm 1.33 \%$ (Sunlight), $90.33 \pm 5.95 \%$ (Surf), $80.16 \pm 2.99 \%$ (Omo), $99.49 \pm 3.11 \%$ (Ariel), and $87.19 \pm 0.26 \%$ (Maq).
\end{abstract}

Conclusion: The remarkable stability of the keratinase with an admixture of organic solvents or laundry detergents portends the industrial and biotechnological significance of the biocatalyst.

Keywords: Keratinase, Bacillus sp., Chicken feathers, Valorization, Thiol group, Laundry detergent

\section{Background}

Keratinases (EC 3.4.21/24/99.11) are inducible proteolytic enzymes that mediate the bioconversion of insoluble keratinous protein into smaller organic molecules including functional peptides and amino acids [1]. The enzymes have been reported to disintegrate keratin either in synergy [2], or isolation [3] of sulfitolytic systems. Keratinases are mostly serine or metallo-class of protease, and are distinct

\footnotetext{
* Correspondence: UNwodo@ufh.ac.za

'SAMRC Microbial Water Quality Monitoring Centre, University of Fort Hare, Alice 5700, South Africa

${ }^{2}$ Applied and Environmental Microbiology Research Group (AEMREG), Department of Biochemistry and Microbiology, University of Fort Hare, Private Bag X1314, Alice 5700, South Africa
}

from classic proteases owing to their ability to degrade keratin which is the major structural constituent of avian feathers, hair, hooves, nails and horns.

Keratinous biomass are generated in significant quantities from commercial slaughterhouses, and poultry and leather processing industries [4]. The recalcitrant tendency of keratinous residues poses disposal challenge which leads to a localized accumulation, and that ultimately constitute environmental nuisance [1]. Globally, avian feathers are generated in large quantities annually, and the trend should be in the upward trajectory as the demand for white meat rises with the ever-growing world population [5].

Chicken feathers account for about $5-7 \%$ of the total weight of a chicken [6]. Therefore, the keratinous waste

(c) The Author(s). 2020 Open Access This article is licensed under a Creative Commons Attribution 4.0 International License, which permits use, sharing, adaptation, distribution and reproduction in any medium or format, as long as you give appropriate credit to the original author(s) and the source, provide a link to the Creative Commons licence, and indicate if changes were made. The images or other third party material in this article are included in the article's Creative Commons licence, unless indicated otherwise in a credit line to the material. If material is not included in the article's Creative Commons licence and your intended use is not permitted by statutory regulation or exceeds the permitted use, you will need to obtain permission directly from the copyright holder. To view a copy of this licence, visit http://creativecommons.org/licenses/by/4.0/. The Creative Commons Public Domain Dedication waiver (http://creativecommons.org/publicdomain/zero/1.0/) applies to the data made available in this article, unless otherwise stated in a credit line to the data. 
emanating from poultry processing farms are enormous and presents major concerns to the environmentalists. In the Republic of South Africa, about two hundred and thirty million kilograms $\left(230 \times 10^{6} \mathrm{~kg}\right)$ of chicken feathers are generated per annum [7], due to the promotion of local productions and imposition of anti-dumping duties on importation of poultry meats from Brazil and other top players in the industry [8]. Since the demand for these agro residues is unfortunately low, feathers are predominantly landfilled or incinerated [9]. A number of approaches have been used to add economic value to the protein-rich poultry feathers, and that includes the adoption of endergonic-mechanical method for the conversion of feathers into feedstuffs (feather meal) by some agro-industry [10]. The valorization process is sometimes used for the extraction of pure keratin from feathers via the application of organic/inorganic chemicals [11]. However, all this approach is expensive and not environmentally friendly. On a similar note, the physical-mechanical valorization approach always, is, saddled with loss of essential constituents in the feather meal [12].

The bio-based approach for the valorization of poultry feathers (keratin-rich polymer) represents an efficient route for novel products. Therefore, it portends an effective and sustainable reintegration of the agro residues into a value chain for the bio-economy [13]. Consequently, some microbes including bacteria, actinobacteria and fungi have expressed keratinolytic potentials $[14,15]$. The bacteria have been the most explored, and Bacillus spp. are the lead keratinase producers [16]. The biodegradation of keratinous wastes may serve a multiple beneficial purpose including the production of economically viable microbial metabolites, the generation of degradation products with economic value, and the promotion of a cleaner environment [17]. Extracellular keratinase production by microorganisms differs significantly because of the salient variations of keratinolytic microbial strains. The optimization process, either through classical or statistical method, has been employed to enhance keratinase yield from various wild bacterial isolates, as keratinase production is grossly influence by physical and nutritional factors. The construction of optimal physico-chemical conditions improved the keratinase production from Alcaligenes sp. AQ05-001 by a 10-fold increase [17]. Similarly, Tiwary and Gupta [18] reported an enhanced extracellular keratinase secretion from a feather-degrading Bacillus licheniformis ER-15 after the optimization of the process conditions.

Keratinases have potential applications in various sectors including the leather production, detergent formulation, pharmaceuticals and biomedicine [12, 14], not only because of their catalytic efficiency, but also due to sustainable production on a cost-effective renewable resource. The ability of keratinases to hydrolysis both the soluble and insoluble proteinaceous stains; and robustness in the presence of chemical agents promoted their industrial significance as bio-additive for detergent formulation [19]. Moreover, keratinases possess boisterous tendencies suitable for green technology. Therefore, continuum in the search for a novel keratinase producer from diverse environment is an imperative. This study was undertaken to enhance the extracellular keratinase activity of Bacillus sp. CSK2 via the process conditions optimization. The properties of the extracellularly secreted keratinase were determined, and the putative keratinase coding gene was amplified, sequenced and the sequence analyzed for novel properties.

\section{Results}

\section{Optimization of physico-chemical process}

The initial medium $\mathrm{pH}$ was varied from 3.0 to 11.0 and results showed that Bacillus sp. CSK2 significantly produced extracellular keratinase at a broad range of $\mathrm{pH}$ (3.0-9.0), with the maximum activity of $707.27 \pm 5.14 \mathrm{U} /$ $\mathrm{mL}$ at $\mathrm{pH} 5.0$ (Fig. 1a). Above $\mathrm{pH} 9.0$, the enzyme production declined considerably, with keratinase activity of $227.27 \pm 12.85 \mathrm{U} / \mathrm{mL}$ and $219.09 \pm 24.42 \mathrm{U} / \mathrm{mL}$ at $\mathrm{pH} 10.0$ and 11.0, respectively. The protein concentration was quantified from the cell-free broth, and the results indicated that the protein content was relatively constant at weakly acidic conditions ( $\mathrm{pH} 3.0-6.0)$. The concentration of protein signifcantly increased after $\mathrm{pH} 6.0$, with the maximum concentration of $808.03 \pm 14.48 \mu \mathrm{g} / \mathrm{mL}$ at $\mathrm{pH}$ 11.0 (Fig. 1a).

The incubation temperature of the fermentation flasks was varied and the results indicated that Bacillus sp. CSK2 produced keratinase in all the evaluated temperatures $\left(25-40^{\circ} \mathrm{C}\right)$. The optimum keratinase activity of $819.09 \pm 24.42 \mathrm{U} / \mathrm{mL}$ was obtained at $30^{\circ} \mathrm{C}$ (Fig. 1b). Above $30{ }^{\circ} \mathrm{C}$, the enzyme production decreased consistently from $35^{\circ} \mathrm{C}$ to $40^{\circ} \mathrm{C}$, with respective keratinase activity of $711.82 \pm 16.71 \mathrm{U} / \mathrm{mL}$ and $609.09 \pm 17.99 \mathrm{U} /$ $\mathrm{mL}$. The protein concentration showed similar pattern as enzyme activity, with the maximum concentration of $596.87 \pm 47.91 \mu \mathrm{g} / \mathrm{mL}$ at $30^{\circ} \mathrm{C}$.

The effect of static condition and different agitation speeds on keratinase production by Bacillus sp. CSK2 was assessed. The results showed that the isolate produced enzyme at static condition $(565.45 \pm 7.71 \mathrm{U} / \mathrm{mL})$, but the activity was significantly enhanced by the agitation speed, with the highest enzyme activity of $1374.54 \pm 53.99 \mathrm{U} / \mathrm{mL}$ obtained at $200 \mathrm{rpm}$ (Fig. 1c). Similarly, the maximum protein concentration of $819.06 \pm 32.31 \mu \mathrm{g} / \mathrm{mL}$ was obtained at $200 \mathrm{rpm}$. Beyond optimum, both enzyme activity and concentration of protein showed drastic decrease at $250 \mathrm{rpm}$.

Subsequently, the fermentation medium was supplementation with various carbon sources, and the extracellular 

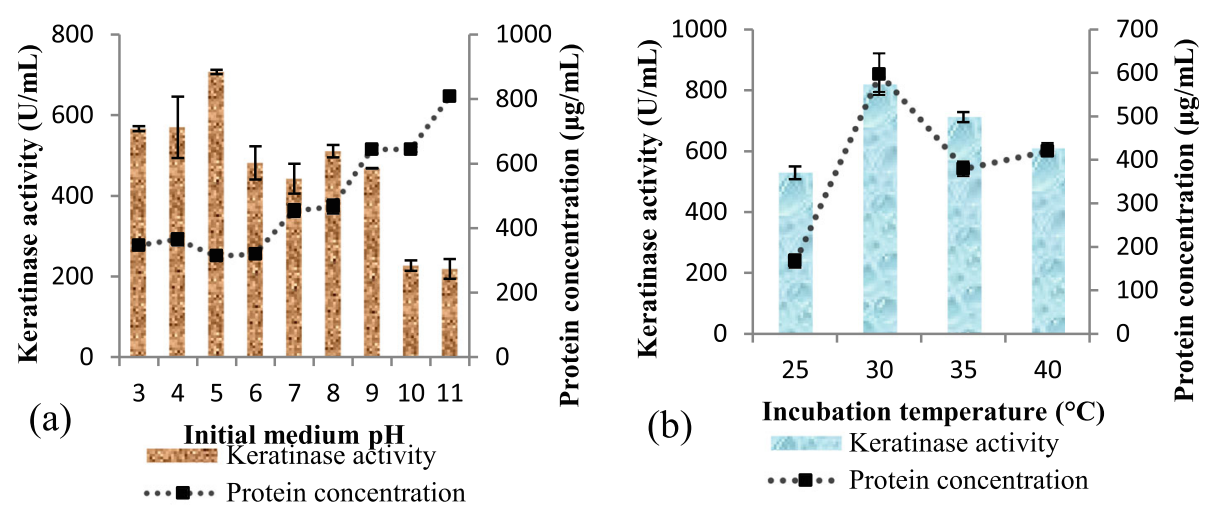

(b)

Incubation temperature $\left({ }^{\circ} \mathrm{C}\right)$

nesuratinase activity

..๑. Protein concentration

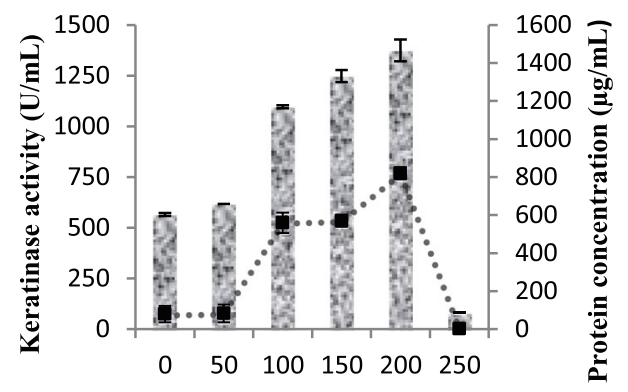

(c)

Agitation speed (rpm)

nseve Keratinase activity

..... Protein concentration

Fig. 1 Effect of a initial medium pH (3.0-11.0) $\mathbf{b}$ incubation temperature $\left(25-40^{\circ} \mathrm{C}\right)$ and $\mathbf{c}$ agitation speed $(0-250$ rpm) on extracellular keratinase production by Bacillus sp. CSK2

keratinase activity of Bacillus sp. CSK2 was promoted in the presence glucose, xylose, fructose, lactose, maltose, sucrose and soluble starch when compared to the control with respective enzyme activity of $987.27 \pm 2.57 \mathrm{U} / \mathrm{mL}$, $801 \pm 5.14 \mathrm{U} / \mathrm{mL}, \quad 890.90 \pm 20.57 \mathrm{U} / \mathrm{mL}, \quad 765.45 \pm 2.50 \mathrm{U} /$ $\mathrm{mL}, \quad 1142 \pm 57.85 \mathrm{U} / \mathrm{mL}, \quad 788.18 \pm 124.70 \mathrm{U} / \mathrm{mL} \quad$ and $780.90 \pm 24.43 \mathrm{U} / \mathrm{mL}$ (Fig. 2a). The maximum stimulatory effect was obtained after maltose supplementation. The supplementation of the medium with mannitol, galactose and sorbitol did not produce any conspicuous effect when compared to the control. The protein concentration fluctuated across the different carbon sources employed with the highest concentrations of $443.23 \pm 0 \mu \mathrm{g} / \mathrm{mL}$ and $452.68 \pm$ $2.22 \mu \mathrm{g} / \mathrm{mL}$ recorded against fructose and soluble starch, respectively. The influence of maltose concentration was further assessed, and the finding indicated that $2 \mathrm{~g} / \mathrm{L}$ was optimal for keratinase activity of Bacillus sp. CSK2 (Fig. 2b). Also, the concentration of the protein was the maximum at $2.0 \mathrm{~g} / \mathrm{L}$, and subsequently decreased with higher maltose concentration.

The influence of various concentrations of chicken feathers on extracellular keratinase production by Bacillus sp. CSK2 was further studied. The obtained results highlighted that increasing concentration of chicken feathers from 1.0, 2.5, 5.0 to $7.5(\mathrm{~g} / \mathrm{L})$ resulted in stepwise increase in extracellular keratinase activity from $285.45 \pm$ $30.85 \mathrm{U} / \mathrm{mL}, 499.09 \pm 1.28 \mathrm{U} / \mathrm{mL}, 777.27 \pm 98.99 \mathrm{U} / \mathrm{mL}$, to $957.27 \pm 3.85 \mathrm{U} / \mathrm{mL}$, respectively (Fig. 2c). Beyond the optimum concentration $(7.5 \mathrm{~g} / \mathrm{L})$, extracellular keratinase production dropped in a consistent manner with increasing chicken feathers concentration; presenting the least enzyme activity of $549.09 \pm 20.57 \mathrm{U} / \mathrm{mL}$ at $17.5 \mathrm{~g} / \mathrm{L}$. The medium protein content increased as higher amounts of chicken feathers were utilized for the fermentation and the maximum concentration of $733.17 \pm 24.51 \mu \mathrm{g} / \mathrm{mL}$ was recorded at $17.5 \mathrm{~g} / \mathrm{L}$.

\section{The time course study of keratinase activity}

The time course of keratinase production by Bacillus sp. CSK2 was evaluated for $120 \mathrm{~h}$. Keratinase production began during the exponential growth phase of the isolate and subsequently peaked at $48 \mathrm{~h}$ of incubation period with keratinase activity of $1539.09 \pm 68.14 \mathrm{U} / \mathrm{mL}$ (Fig. 3). Beyond $48 \mathrm{~h}$, the enzyme activity consistently declined, reaching $869.99 \pm 1.28 \mathrm{U} / \mathrm{mL}$ at $120 \mathrm{~h}$. The protein and thiol concentrations peaked at $72 \mathrm{~h}$ with respective concentrations of $758.39 \pm 11.14 \mu \mathrm{g} / \mathrm{mL}$ and $492.98 \pm$ $82.99 \mu \mathrm{M}$ (Fig. 3). Extension of the fermentation period resulted in drastic decrease of the both protein and thiol concentrations. The evaluation of $\mathrm{pH}$ change over the 


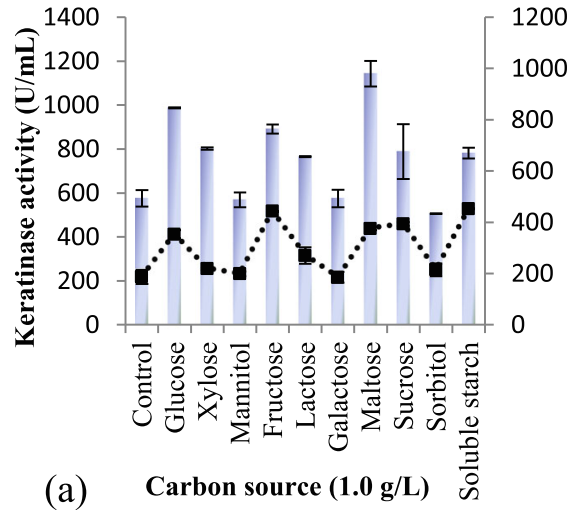

Keratinase activity Protein concentration

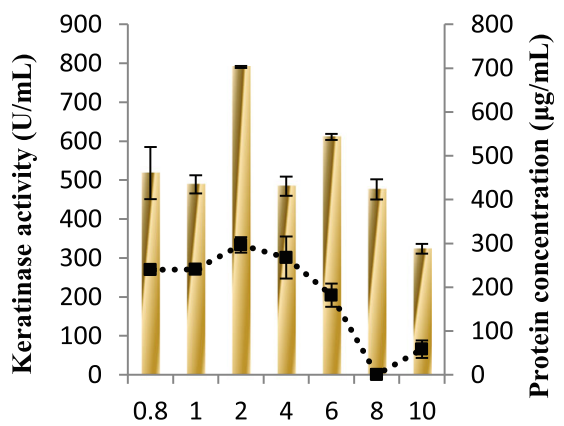

Maltose concentration (g/L)

(b)

......Protein concentration

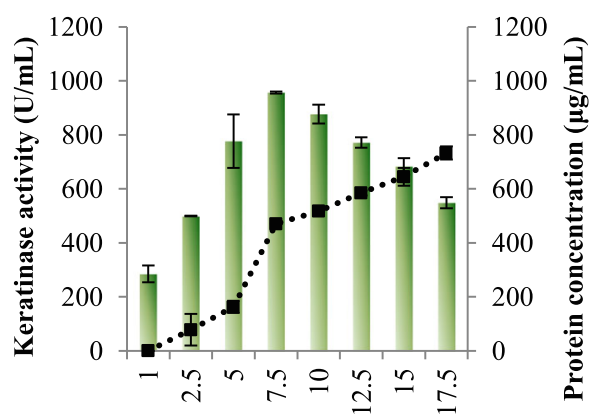

(c)

Chicken feathers (g/L)

Keratinase activity

... $\square . . P$ Protein concentration

Fig. 2 Effect of a carbon source supplementation $(1.0 \mathrm{~g} / \mathrm{L}) \mathbf{b}$ maltose concentration $(0.8-10.0 \mathrm{~g} / \mathrm{L})$ and $\mathbf{c}$ chicken feather concentration $(1.0-17.5$ $\mathrm{g} / \mathrm{L}$ ) on extracellular keratinase production by Bacillus sp. CSK2

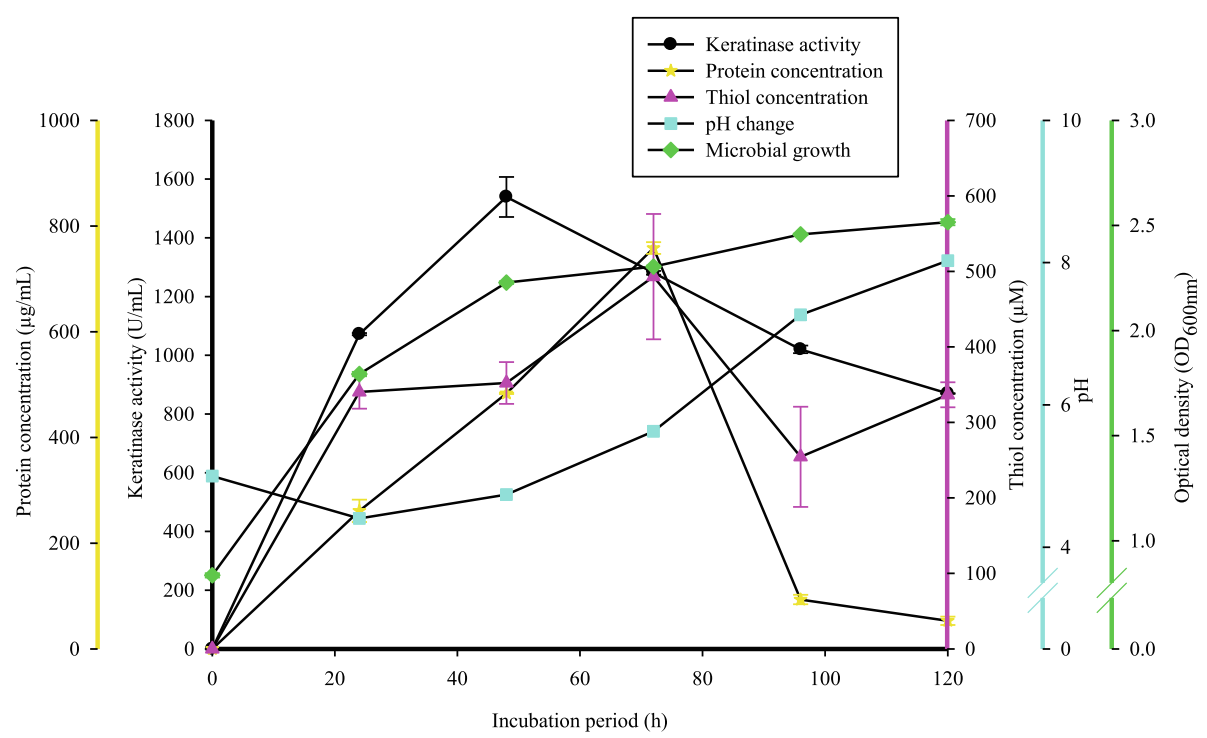

Fig. 3 The time course study of keratinolytic activity of Bacillus sp. CSK2 at optimized conditions over the incubation period of $120 \mathrm{~h}$. Aliquots were periodically ( $24 \mathrm{~h}$ ) withdrawn in an aseptic condition to determine keratinase activity (black), protein concentration (yellow), thiol concentration (pink), pH change (cyan) and cell growth (green) 
course of fermentation showed that the fermentation medium $\mathrm{pH}$ dropped after $24 \mathrm{~h}$ of incubation from initial value of 5.0 to $4.4 \pm 0.12$ (Fig. 3); thereafter, it increased consistently following the extension of cultivation period with the maximum value of $8.03 \pm 0.02$ at $120 \mathrm{~h}$.

\section{Enzyme characterization}

\section{Effect of $\mathrm{pH}$ on keratinase activity and stability}

The evaluation of the $\mathrm{pH}$ influence on keratinase activity indicated that the keratinolytic enzyme was catalytically active from weakly acidic condition to alkaline condition (Fig. 4a). The keratinase displayed the optimum activity at $\mathrm{pH}$ 8.0. It barely showed activity at $\mathrm{pH} \mathrm{5.0;} \mathrm{while} \mathrm{it}$ presented about $48 \%$ relative activity at $\mathrm{pH} 9.0$ and further declined with increasing alkalinity. Subsequently, the evaluation of the keratinase stability at different $\mathrm{pH}$ values (6.0-9.0) showed that the enzyme was remarkably stable, retaining $91.97 \pm 0.15,97.97 \pm 3.36,97.99 \pm 3.83$ and $94.96 \pm 1.29(\%)$ of the original activity at respective $\mathrm{pH}$ 6.0, 7.0, 8.0, and 9.0 after $4 \mathrm{~h}$ of preincubation (Fig. $4 \mathrm{~b}$ ).

\section{Effect of temperature on keratinase activity and stability}

The temperature profile of Bacillus sp. CSK2 keratinase was presented in Fig. 5. The enzyme was active at a broad temperature range $\left(30-80^{\circ} \mathrm{C}\right)$, and the activity increased following the rise in temperature with the highest activity at $60^{\circ} \mathrm{C}$ (Fig. 5a). However, there was no significant difference between keratinase activity at $60^{\circ} \mathrm{C}$ and $70^{\circ} \mathrm{C}$ or $80^{\circ} \mathrm{C}$ as the relative activities at latter temperatures were $94.30 \pm 4.10 \%$ and $89.22 \pm 0.15 \%$, respectively.

Furthermore, the keratinase solution was subjected to heat pretreatment at $50^{\circ} \mathrm{C}, 60^{\circ} \mathrm{C}$ and $70^{\circ} \mathrm{C}$ for $2 \mathrm{~h}$, and the findings indicated that the study enzyme was remarkably stable with respectively residual activity of $86.65 \pm 2.76 \%, 84.37 \pm 2.53 \%$, and $59.45 \pm 2.76 \%$ (Fig. 5 b).

\section{Effect of various chemical agents on stability of} keratinase

The keratinase showed complete inhibition with an admixture of metallic ions chelators, EDTA and 1,10-phenanthroline, but retained $89 \pm 6.22 \%$ of the original activity when pretreated with PMSF for 60 min (Table 1). Among all the reducing agents, 2-mercaptoethanol had stimulatory effect on the residual activity $(111 \pm 0.54 \%)$ of the keratinase; while sodium thioglycolate, dithiothreitol and sodium sulfite affected the enzyme stability with residual activities of $64 \pm 2.70 \%, 69 \pm 0.09 \%$ and $78 \pm$ $3.61 \%$, respectively (Table 1 ). Furthermore, the enzyme was remarkably stable $(103 \pm 3.52 \%)$ at $1 \%(\mathrm{v} / \mathrm{v})$ hydrogen peroxide (Table 1). The organic solvent impacted variably on the stability of the keratinase with stimulatory effect demonstrated after DMSO pretreatment $(114 \pm 5.86 \%)$. Contrarily, acetonitrile and propan-2-ol prompted lower stability of the enzyme. The study keratinase showed remarkable stability after pretreatment with non-ionic surfactants, triton X-100 $(99 \pm 2.16 \%)$ and tween-80 (182 $\pm 1.98 \%)$. While the anionic surfactant, SDS caused a reduction of enzyme activity at $5 \mathrm{mM}$ (Table 1).

Effect of various metallic ions on the stability of keratinase The effect of different monovalent, divalent and trivalent metal ions on the enzyme stability was investigated, and the results were presented in Table 2. All the metal ions employed negatively impacted on the stability of the enzyme, with more drastic effect obtained in the presence of trivalent metal ions, $\mathrm{Al}^{3+}(13 \pm 1.35 \%)$ and $\mathrm{Fe}^{3+}(12 \pm 0.36 \%)$.

\section{Laundry detergent effect on the stability of keratinase}

The results from the detergent stability study showed that the crude keratinase maintained remarkable stability in the various laundry detergents employed, with residual
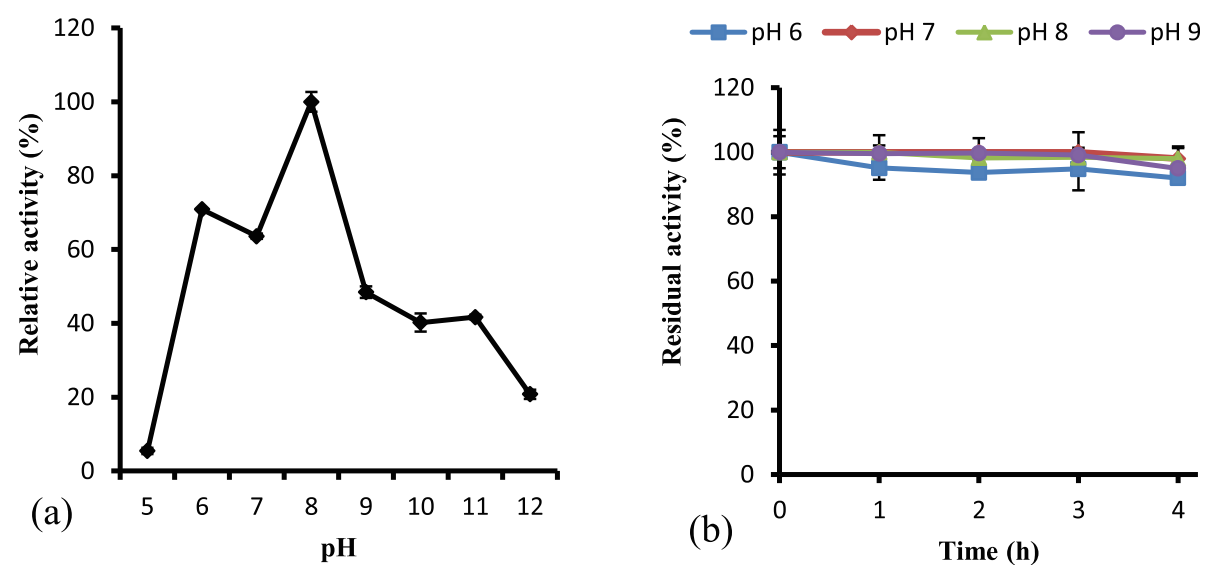

Fig. 4 a Effect of $\mathrm{pH}$ (5.0-12.0) on keratinase activity. The highest enzyme activity was obtained at optimum pH 8.0. b Determination of pH stability of keratinase after $4 \mathrm{~h}$ preincubation at $\mathrm{pH} 6.0,7.0,8.0$ and 9.0 

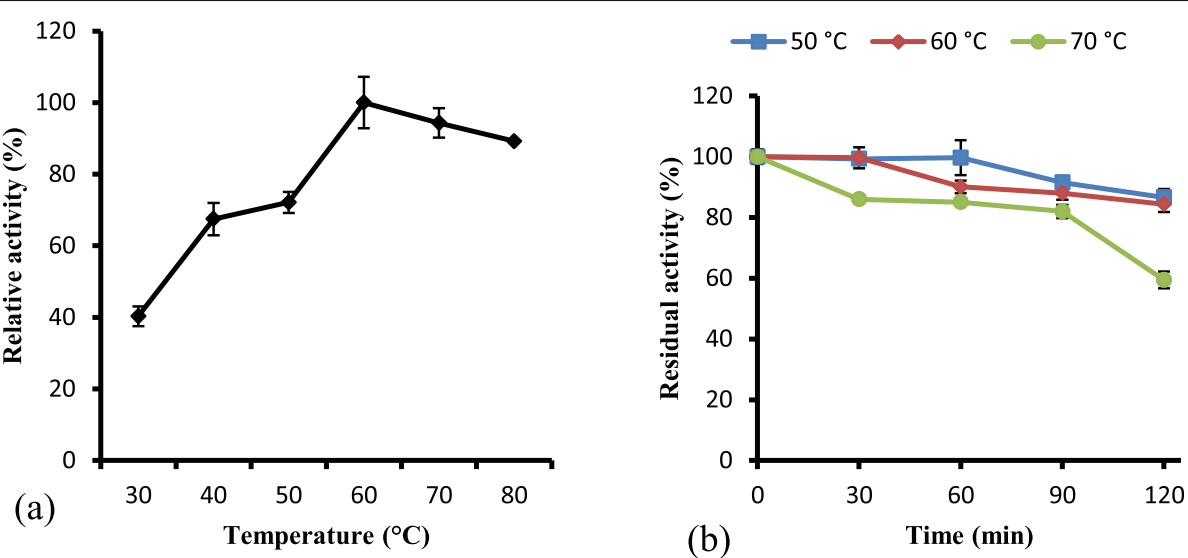

Fig. 5 a Effect of temperature $\left(30-80^{\circ} \mathrm{C}\right)$ on keratinase activity. The optimal temperature for keratinase activity was determined to be in the range of $60-80^{\circ} \mathrm{C}$. b Determination of the thermostability of keratinase after $2 \mathrm{~h}$ of preheating at $50^{\circ} \mathrm{C}, 60^{\circ} \mathrm{C}$ and $70^{\circ} \mathrm{C}$

activity of $85.19 \pm 1.33,90.33 \pm 5.95,80.16 \pm 2.39,99.49 \pm$ 3.11 and $87.19 \pm 0.26$ (\%) for Sunlight, Surf, Omo, Ariel and Maq, respectively (Fig. 6). There was no significant difference $(P>0.05)$ between the residual keratinase activity after the Ariel pretreatment and control (enzyme solution preincubated with tap water only).

\section{Molecular characterization of keratinase}

The gel picture of keratinase encoding gene amplified from Bacillus sp. CSK2 showed band size of $1104 \mathrm{bp}$ (supplementary file). The nucleotide sequence analysis indicated that the putative keratinase gene has 92 and 93\% identity with keratinase genes of Bacillus thuringiensis

Table 1 Effect of various chemical agents on keratinase stability

\begin{tabular}{lll}
\hline Chemical agent & Concentration & Residual activity (\%) \\
\hline None & - & $100 \pm 4.24^{\mathrm{d}}$ \\
EDTA & $5 \mathrm{mM}$ & $0 \pm 0^{\mathrm{a}}$ \\
1,10-phenanthroline & $5 \mathrm{mM}$ & $0 \pm 0^{\mathrm{a}}$ \\
PMSF & $5 \mathrm{mM}$ & $89 \pm 6.22^{\mathrm{c}}$ \\
Sodium thioglycolate & $5 \mathrm{mM}$ & $64 \pm 2.70^{\mathrm{b}}$ \\
Dithiothreitol & $5 \mathrm{mM}$ & $69 \pm 0.09^{\mathrm{b}}$ \\
Sodium sulfite & $5 \mathrm{mM}$ & $78 \pm 3.61^{\mathrm{c}}$ \\
2-Mercaptoethanol & $5 \mathrm{mM}$ & $111 \pm 0.54^{\mathrm{e}}$ \\
Hydrogen peroxide & $1 \%(\mathrm{v} / \mathrm{v})$ & $103 \pm 3.52^{\mathrm{d}}$ \\
Dimethyl sulfoxide & $1 \%(\mathrm{v} / \mathrm{v})$ & $114 \pm 5.86^{\mathrm{e}}$ \\
Acetonitrile & $1 \%(\mathrm{v} / \mathrm{v})$ & $61 \pm 3.34^{\mathrm{b}}$ \\
Propan-2-ol & $1 \%(\mathrm{v} / \mathrm{v})$ & $79 \pm 3.97^{\mathrm{c}}$ \\
Sodium dodecyl sulfate & $5 \mathrm{mM}$ & $77 \pm 4.51^{\mathrm{c}}$ \\
Triton X-100 & $1 \%(\mathrm{v} / \mathrm{v})$ & $99 \pm 2.16^{\mathrm{d}}$ \\
Tween-80 & $1 \%(\mathrm{v} / \mathrm{v})$ & $182 \pm 1.98^{\mathrm{f}}$
\end{tabular}

Superscript letter(s) a, b, c, d, e and f down the column were used to indicate significant difference at $P<0.05$
S3KUBOT (KX155576) and Bacillus cereus Wu6 (HQ694987), respectively. The nucleotide sequence with a $\mathrm{G}+\mathrm{C}$ content of $39.4 \%$ was submitted to the GenBank with the accession number MT268136.

Figure 7 shows the alignment of amino acid sequence deduced from the partial nucleotide sequence with other related keratinase and alkaline protease sequences of $B$. cereus group (sensu lato), including $B$. thuringensis S3KUBOT keratinase (APS24128), B. cereus Wu6 keratinase (AE183225), B. thuringiensis alkaline proteases (AAD48483) and (AAR24606). The keratinase under investigation showed high sequence homology with other related sequences obtained from the protein

Table 2 Metal ion effect on the stability of keratinase

\begin{tabular}{|c|c|c|}
\hline Metal ion & Concentration (mM) & Residual activity (\%) \\
\hline None & - & $100 \pm 4.24^{f}$ \\
\hline $\mathrm{Li}^{+}$ & 5 & $71 \pm 1.71^{e}$ \\
\hline $\mathrm{Na}^{+}$ & 5 & $71 \pm 1.53^{\mathrm{e}}$ \\
\hline $\mathrm{K}^{+}$ & 5 & $71 \pm 4.78^{e}$ \\
\hline $\mathrm{Ag}^{+}$ & 5 & $69 \pm 3.69^{e}$ \\
\hline $\mathrm{Ca}^{2+}$ & 5 & $69 \pm 2.34^{e}$ \\
\hline $\mathrm{Mg}^{2+}$ & 5 & $68 \pm 4.42^{e}$ \\
\hline $\mathrm{Mn}^{2+}$ & 5 & $74 \pm 1.35^{\mathrm{e}}$ \\
\hline $\mathrm{Zn}^{2+}$ & 5 & $69 \pm 0.81^{e}$ \\
\hline $\mathrm{Cu}^{2+}$ & 5 & $45 \pm 2.52^{\mathrm{bc}}$ \\
\hline $\mathrm{Fe}^{2+}$ & 5 & $73 \pm 1.62^{\mathrm{e}}$ \\
\hline $\mathrm{Hg}^{2+}$ & 5 & $43 \pm 2.07^{b}$ \\
\hline $\mathrm{Ba}^{2+}$ & 5 & $55 \pm 3.61^{d}$ \\
\hline $\mathrm{Co}^{2+}$ & 5 & $50 \pm 1.98^{\mathrm{cd}}$ \\
\hline $\mathrm{Al}^{3+}$ & 5 & $13 \pm 1.35^{\mathrm{a}}$ \\
\hline $\mathrm{Fe}^{3+}$ & 5 & $12 \pm 0.36^{a}$ \\
\hline
\end{tabular}

Superscript letter(s) a, b, c, d, e and f down the column were used to indicate significant difference at $P<0.05$ 


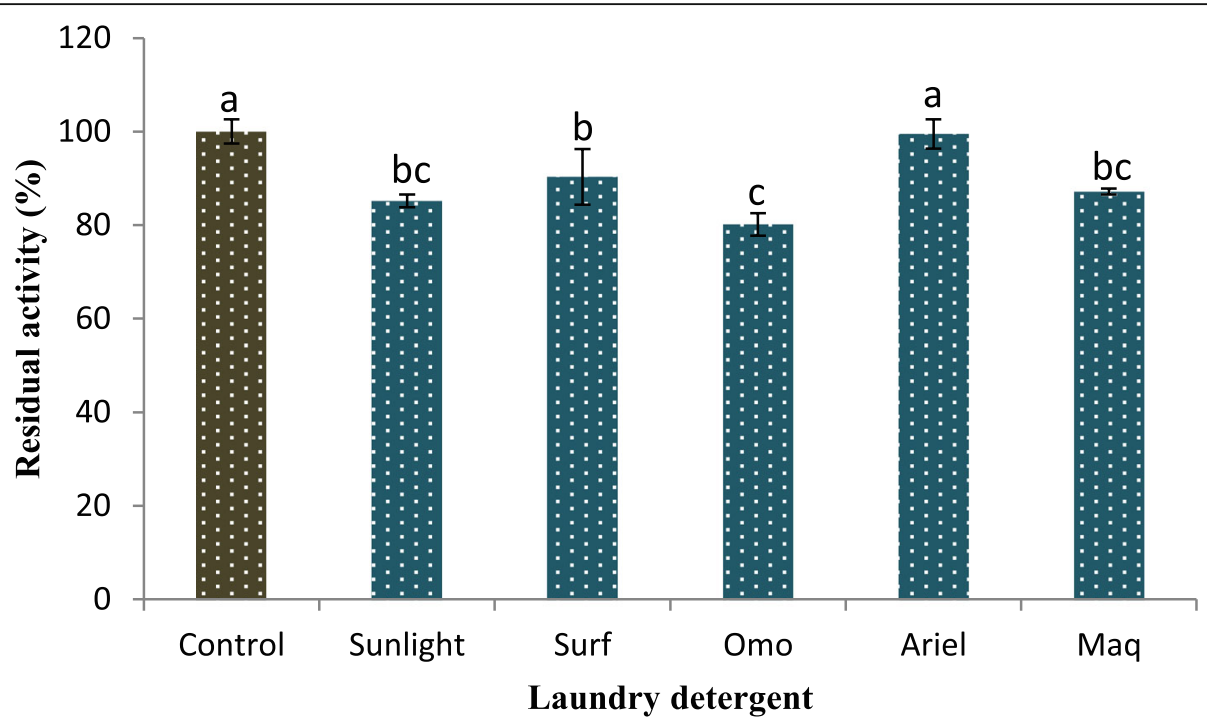

Fig. 6 Laundry detergent impact on keratinolytic protease stability. Letters $a, b$ and $c$ indicate significance difference among the various treatments and points without similar letter(s) are different statistically $(P<0.05)$

database. The dots indicated similar amino acid residues down the column between the study sequence and the reference sequences; while the points of variation are shown by the retention of amino acid residues on the reference sequences (Fig. 7).

\section{Discussion}

The $\mathrm{pH}$ optimum for the extracellular keratinase activity of Bacillus sp. CSK2 was previously demonstrated by a few Bacillus spp. [20, 21]. The optimal extracelular keratinase production at $\mathrm{pH} \leq 6.0$ has been sparcely

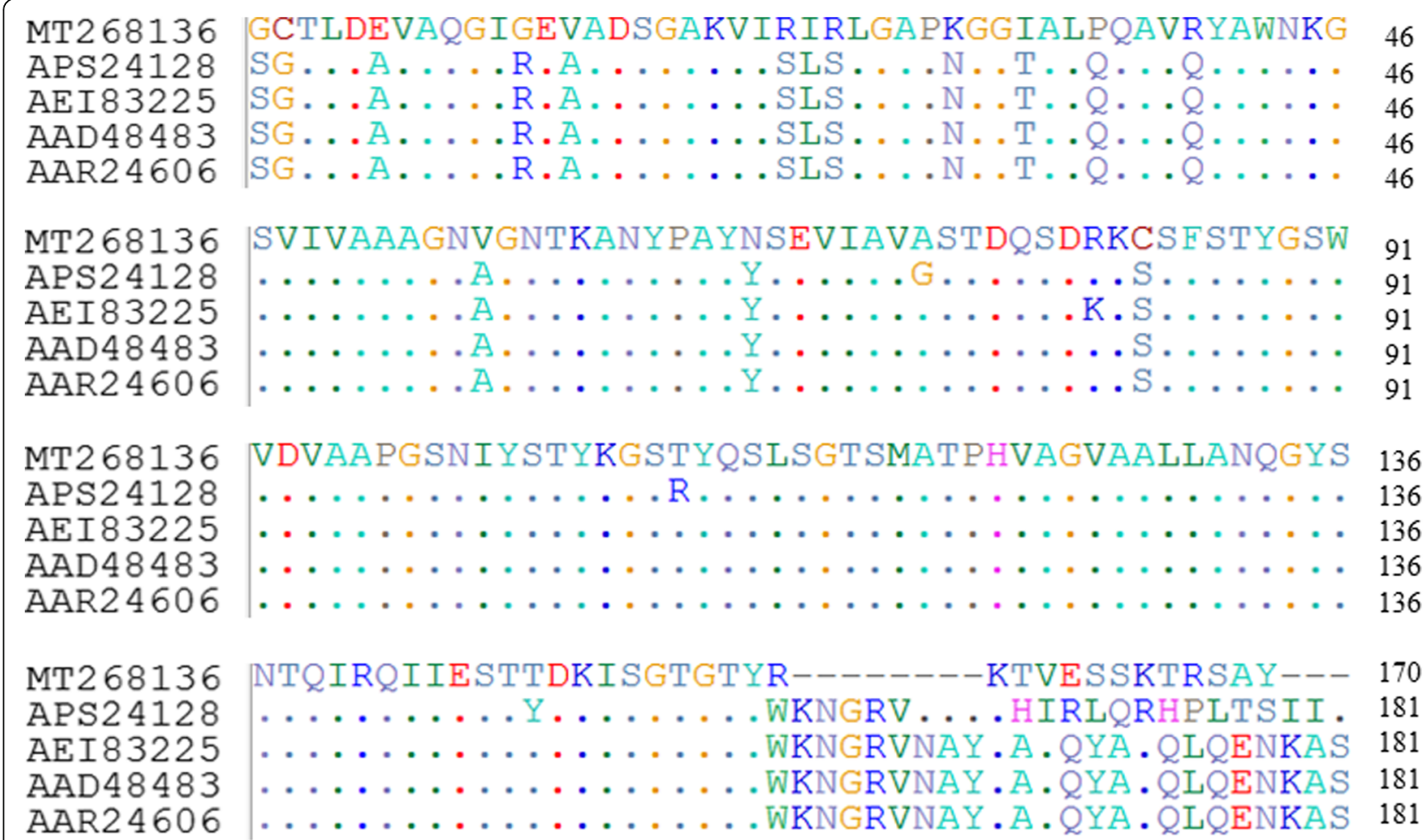

Fig. 7 Multiple amino acid sequences alignment of Bacillus sp. CSK2 keratinase with B. thuringiensis S3KUBOT keratinase (APS24128), B. cereus Wu6 keratinase (AE183225), B. thuringiensis alkaline protease A (AAD48483), and B. thuringiensis alkaline protease A (AAR24606). The dots indicate similar residues between the study keratinase sequence and other sequences from the protein database 
documented, as acidic condition has been described as the limiting factor for the expression of keratinase by most of Bacillus spp. [22, 23]. Generally, keratinolytic bacteria have been described to optimally secrete keratinase at $\mathrm{pH}$ ranging from weakly acidic condition to alkaline spectrum [24]. The higher protein concentration observed at alkaline condition may be attributed to either the elevated production of other proteins that are not keratinase by bacterial isolate or libration of soluble proteins from the feather keratin directed by the basic condition of the medium [25]. It is worthy of note that $\mathrm{pH}$ is an important factor that contributes significantly to the regulation of microbial growth, plasma membrane integrity and transport proteins functionality [24]. Consequently, it influences microbial metabolism and metabolites production via some cascade mechanisms. The ability of Bacillus sp. CSK2 to considerably produce extracellular keratinase at an extended $\mathrm{pH}$ spectrum underpins its biotechnological and indrustrial relevance.

The findings from the temperature optimization suggest that Bacillus sp. CSK2 is a mesophilic bacterium, and this attribute of strain CSK2 is energy saving and economically attractive [26]. This is consistent with other reports on keratinolytic bacteria that presented optimal keratinase production at mesophilic conditions $[22,26,27]$. However, some bacterial strains have been reported to optimally express keratinase at relatively higher temperature [28], including the extremophile Fervidobacterium islandicum AW-1 [29].

The agitation speed optimal is peculiar to bacterial isolate; as such variable optimal agitation rates have been reported for the maximum extracellular keratinase productions [30, 31]. Agitation speed promotes microbial metabolism by ensuring optimal oxygen transfer and effective microbial cell-substrate interactions through medium homogeneity which subsequently enhances cell growth and enzyme production [32]. Nonetheless, higher agitation speed prompts shear forces which affect cell membrane integrity and productivity [32]. Keratinase production by other strains of Bacillus spp. was also enhanced at similar agitation condition [27, 33].

Basically, microbial keratinase production is an inducible process, and it begins when the microbial cells significantly depend on keratinous biomass for homeostasis [21]. The improved enzyme production obtained when the fermentation media were supplemented with low concentration of various assimilable carbon sources may be attributed to the facilitation of the bacteria growth encouraged by the utilizable carbon sources. Simultaneously, the bacterial cells solely relied on the chicken feathers for nitrogen which invariably prompted the upregulation of the keratinase expression, yielding to the significant extracellular enzyme concentration for efficient keratin hydrolysis [34]. The peculiarity of microorganisms influences their preference to carbon sources, hence the observed variation in keratinase production with various supplemented carbon sources [17]. The positive influence of the various carbon sources supplemented has been reported in similar studies $[18,26,35]$.

As reported in similar studies, the maximum keratinase production by some bacterial species was obtained using the concentration of chicken feathers that ranged from $5.0 \mathrm{~g} / \mathrm{L}$ to $10.0 \mathrm{~g} / \mathrm{L}$ [17, 23, 26, 27]. Conversely, keratinase production by Stenotrophomonas maltophilia [35] and Xanthomonas sp. P5 [36] was optimum in media formulated with $2.0 \mathrm{~g} / \mathrm{L}$ and $1.0 \mathrm{~g} / \mathrm{L}$ of chicken feathers, respectively. As an inducible enzyme, it was expected that the extracellular keratinase activity would have increased with higher concentrations of chicken feathers, but that did not happen, instead protein concentration increased consistently. This observed trend of high protein content at higher concentration of chicken feathers may be attributed to the medium accumulation of soluble proteins emanating from keratin hydrolysis by active extracellular keratinase. These assimilable products would prompt the down-regulation of keratinase expression via product inhibition mechanism [15], hence the decrease in the concentration of extracellular keratinase. The finding is consonant with the previous reports [26, 27].

The findings from the time course study suggest that keratinase production by Bacillus sp. CSK2 was associated with primary metabolism [27]; and the keratinase production in optimized conditions was enhanced 3.4-folds when compared to the unoptimized condition [16]. Similarly, $\mathrm{He}$ et al. [37] reported the highest keratinase production of $21.6 \mathrm{U} / \mathrm{mL}$ by $B$. subtilis 8 at $48 \mathrm{~h}$ of fermentation. Likewise, S. maltophilia R13 presented optimum extracellular keratinase activity of $82.3 \pm 1.0 \mathrm{U} / \mathrm{mL}$ after $48 \mathrm{~h}$ of incubation period [35]. The efficient keratinase secretion potential of Bacillus sp. CSK2 within the established short time frame portends its relevance in industry and biotechnology. Keratin is a recalcitrant biopolymer stabilized by cystine disulfide cross linkages. The detection of thiol groups in the fermentation broth may indicate the reduction of densely populated disulfide bonds of feather keratin into bioavailable products, and the thiol concentration may suggest the biocatalytic efficiency of the keratinolytic and/ or sulfitolytic systems $[24,38]$. The thiol concentration determined in the present study is significantly higher than that reported in the previous studies, where maximum thiols of $44.5 \pm 1.8 \mu \mathrm{M}$ [35], $82 \mu \mathrm{M}$ [39], and 5.4 \pm $0.4 \mu \mathrm{M}$ [37] were obtained at $24 \mathrm{~h}, 72 \mathrm{~h}, 96 \mathrm{~h}$ and $120 \mathrm{~h}$ of incubation period, repectively. This attribute of Bacillus sp. CSK2 highlights its dexterity in the valorization of keratinous wastes. Bioconversion of keratin-rich biomass potentiates the ammonification of a culture medium through deamination of free amino groups containing 
degradation products and this process tends to shift the medium $\mathrm{pH}$ toward alkalinity [18, 38]. The initial slight decrease of culture $\mathrm{pH}$ may be attributed to the organic acids emanating from the primary metabolic activity of the isolate. The growth of keratinolytic B. lichenifoirmis ER-15 [18] and Xanthomonas sp. P5 [37] on chicken feathers lowered the medium $\mathrm{pH}$ in like manner.

Change in $\mathrm{pH}$ instigates protonation or deprotonation of protein side chain residues which may affect enzyme - substrate binding and product formation through alteration of the enzyme conformation [39]. As observed from the study keratinase, more drastic effect of $\mathrm{pH}$ on biocatalyst may lead to complete loss of activity. The $\mathrm{pH}$ optima of bacterial keratinases have been extensively documented within the range of 7.0 to 9.0 [24, 40]. However, some reports on alkalophilic keratinase abound with $\mathrm{pH}$ optima $\geq 11.0$ [4]. The $\mathrm{pH}$ stability of the keratinase may be likened to that demonstrated by the alkaline keratinase from B. thuringiensis MT1 [12] and Bacillus subtilis RSE163 [41]. Conversely, Bacillus sp. CSK2 keratinase $\mathrm{pH}$ stability was superior to that reported for Bacillus altitudinis RBDV1 keratinase [42]. Therefore, the considerable $\mathrm{pH}$ stability of this enzyme supports its potential application in detergent formulation where most promising proteases operate between $\mathrm{pH}$ range of 7.0 and 10.0 [39].

The broad thermal activity exhibited by the study enzyme is consistent with most of the documented optimal temperatures of keratinases [24]. The maximum biocatalytic efficiency of $B$. licheniformis RPK keratinase was obtained at $60^{\circ} \mathrm{C}$ [43]. However, extremophilic keratinase from $F$. islandicum AW-1 was optimally active at $100{ }^{\circ} \mathrm{C}$ [29]. The broad temperature tolerance of the keratinase from Bacillus sp. CSK2 suggests the amplitude of its relevance in biotechnology and industry. An alkaline keratinase from Bacillus halodurans PPKS-2 displayed similar thermostability pattern as reported in the present study [44]. Contrariwise, Bacillus pumilus A1 keratinase retained $30.3 \%$ of the original activity after $1 \mathrm{~h}$ of heating at $60^{\circ} \mathrm{C}$ [45]. Additionally, thermostability profiles of keratinases from Bacillus spp. showed that at $60^{\circ} \mathrm{C}$ and $70^{\circ} \mathrm{C}$ after $1 \mathrm{~h}$ of preincubation, the residual activities of 30 and $7 \%$ were retained by BPker, and 37 and 15\% were retained by BAker [46]. The temperature stability of the presently characterized keratinase supports its future applicability in green technological processes.

The sensitive of the enzyme under investigation to the protease inhibitors suggests that it belongs to the metalloclass of keratinase [47-49]. The removal of inherent metallic ions from proteolytic enzyme by chelating agents perturbs the activity of the protein by destabilizing the catalytic conformation which subsequently affects enzymesubstrate binding and product formation [45, 50]. Metallokeratinase from Chryseobacterium sp. was catalytically stimulated by 2-mercaptoethanol [50]. Conversely, stability of metallo-keratinase from Microbacterium sp. kr10 was greatly affected by $0.5 \%(\mathrm{v} / \mathrm{v})$ 2-mercaptoethanol, retaining about $14 \%$ of the original activity [51]. Generally, reducing agents have been implicated in the perturbation of keratinase stability by reducing the intra-molecular disulfide bonds that are involved in structural stabilization [2, 52]. The considerable stability of the keratinase in oxidizing agent portends its industrial potentials including the production of bleach based detergents and similar stability pattern was reported for keratinase from $B$. subtilis RSE163 [41]. The biocatalysis promotion by DMSO and destabilization of keratinase catalytic efficiency by various organic solvents were reported previously [42, 46, $50,53]$. It is worthy of note that tween- 80 promoted keratinase activity by $82 \%$, and this property of the study enzyme is similar to that reported for Brevibacillus sp. AS-S10-II keratinase which has been advanced as good candidate for detergent formulation [52].

Metallo-keratinases have shown to display variable metallic ions tolerance [47, 48, 51]. Zhang et al. [49] reported that keratinase from Brevibacillus parabrevis was selectively activated at $1 \mathrm{mM}$ metal ions, and further increase in the concentration of metal ions up to $5 \mathrm{mM}$ strongly impacted the stability of the enzyme. Additionally, Bacillus subtilis KD-N2 keratinase was significantly inhibited by all the metal ions tested at $5 \mathrm{mM}$ final concentration [53]. Metallic ions influence the activity of a protein by allosteric regulation through complexation with essential residues which induces disorientation of the proper enzyme conformation that encourages substrate binding [6]. Therefore, at high concentrations of metal ions, the catalytic efficiency of metallo-keratinase may be hindered via the process of ionic tethering and electrostatic interaction [50,54].

Keratinolytic protease from B. halotelerans CT2 demonstrated similar significant residual activity after pretreatment with selected commercial laundry detergents [55]. Likewise, crude keratinase from B. pumilus GRK showed considerable residual activity in the range of $80.32 \pm 0.05-93.27 \pm 0.16 \%$ after $60 \mathrm{~min}$ of pretreatment with $0.7 \%(\mathrm{w} / \mathrm{v})$ of the various laundry detergents used [27]. Conversely, the stability of the study enzyme was remarkably higher than Paenibacillus woosongensis crude keratinase that showed a range of $48.1-70.4 \%$ residual activity under similar treatment conditions [19]. Recently characterized alkaline protease from Bacillus safensis retained $75 \%$ of the original activity after preincubation with Ariel $(7.0 \mathrm{mg} / \mathrm{mL})$ [56]. The detergent ingredients including fiber brighteners, foam regulators, bleaching agents, re-deposition agents, surfactants, softening builders, among others have been reported to affect the stability of detergent's endogenous protease $[27,52]$. Therefore, the ability of the study keratinase to 
maintain significant stability in the presence of the various laundry detergents tested suggests its potential candidacy in detergent formulation.

The successful amplification of the keratinase gene therefore buttressed the keratinolytic efficiency of Bacillus sp. CSK2 [16], and may enhance the biotechnological exploitation through heterologous overexpression and molecular optimization. The variation in sequence residues suggests that Bacillus sp. CSK2 keratinase is a novel protein. To date, a collection of bacterial species has been reported to exhibit keratinolytic potentials, but a few of these isolates have had their keratinase encoding genes successfully sequenced. Therefore, this augurs well for the biotechnology and industry, as extracellular secretion of important biomolecules by microbial producers represents a cost-effective process from the economic viewpoint.

\section{Conclusion}

In this study, Bacillus sp. CSK2 keratinase production spiked at $48 \mathrm{~h}$ in a relatively cheap medium comprising chicken feathers as the only source of nitrogen. The produced keratinase showed optimal activity at $\mathrm{pH} 8.0$ and $60-80^{\circ} \mathrm{C}$; with remarkable $\mathrm{pH}$ and thermal stability. The keratinolytic protease demonstrated remarkable stability $(>80 \%)$ after pretreatment with some selected commercial laundry detergents. This property suggests its potential application as bio-additive in detergents formulation. Furthermore, the putative keratinase encoding gene of Bacillus sp. CSK2 was successfully amplified and it showed high percentage similarity with keratinase genes from B. cereus group (sensu lato). Therefore, this substantively reaffirmed the keratinolytic property and extracellular keratinase secretion reported for Bacillus sp. CSK2. Evaluation of the amino acid sequence residues of the delineated gene showed that the keratinase is novel and structurally stable. This study serves a lead to unravel the biotechnological and industrial prospects of Bacillus sp. CSK2 keratinase; hence, scale-up production of this novel keratinase is imperative and would be focused on through molecular cloning and heterologous expression of the enzyme in a suitable industrial host.

\section{Methods}

\section{Isolate and inoculum preparation}

The keratinolytic bacterial isolate - Bacillus sp. CSK2 (MG215005) used for this research was previously isolated from dumpsite soil sample [16]. The pure bacterial culture maintained on powdered chicken feathers (PCF) constituted agar slant was used to inoculate basal salt medium (BSM) containing g/L of $\mathrm{K}_{2} \mathrm{HPO}_{4}, 0.3 ; \mathrm{KH}_{2} \mathrm{PO}_{4}$, $0.4 ; \mathrm{MgCl}_{2}, 0.2 ; \mathrm{CaCl}_{2}, 0.22$; PCF, 10.0 and incubated for $48 \mathrm{~h}$ under agitation $(130 \mathrm{rpm})$ at $30^{\circ} \mathrm{C}$. Subsequently, a loopful of the passaged culture was streaked on a freshly prepared PCF-agar plate containing BSM in addition of bacteriological agar $(15.0 \mathrm{~g} / \mathrm{L})$. The plate was incubated for $18 \mathrm{~h}$ at $30^{\circ} \mathrm{C}$; thereafter, the cells were harvested into a microtube containing sterile saline $(8.5 \mathrm{~g} / \mathrm{L} \mathrm{NaCl})$. The optical density of the bacterial suspension was adjusted to 0.1 at $600 \mathrm{~nm}$ using spectrophotometer. The bacterial suspension served as the fresh inoculum for the fermentation process.

\section{Submerged fermentation and keratinase extraction}

The production medium contained $\mathrm{g} / \mathrm{L}$ of $\mathrm{K}_{2} \mathrm{HPO}_{4}, 0.3$; $\mathrm{KH}_{2} \mathrm{PO}_{4}, 0.4 ; \mathrm{MgCl}_{2}, 0.2 ; \mathrm{CaCl}_{2}, 0.22$, PCF, 7.5; sucrose, 2.0 in Erlenmeyer flasks $(500 \mathrm{~mL})$ containing $100 \mathrm{~mL}$ working volume. The flasks were sterilized in an autoclave (Already Enterprise Inc., Taiwan), and the initial $\mathrm{pH}$ was aseptically adjusted to 5.0 with the aid of JENWAY pH meter (Bibby Scientific Ltd., UK). The inoculation of the flasks was done with $2 \%(\mathrm{v} / \mathrm{v})$ of the freshly prepared bacterial suspension and incubated for $48 \mathrm{~h}$ at $30^{\circ} \mathrm{C}$ and $200 \mathrm{rpm}$. After the fermentation, supernatant was recovered using the centrifuge (Beckman Coulter, Inc. USA) at $15,000 \mathrm{rpm}$ for $15 \mathrm{~min}$ and $4{ }^{\circ} \mathrm{C}$. The supernatant served as crude keratinase and was utilized for the subsequent analytical studies without further purification.

\section{Keratinase activity assay}

Keratinase activity was determined in the crude extract by using the previous [4], with slight modifications [15]. Briefly, $0.5 \mathrm{~mL}$ of $10 \mathrm{~g} / \mathrm{L}$ of keratin azure (Sigma-Aldrich, USA) suspended in $0.1 \mathrm{M}$ Tris- $\mathrm{HCl}$ buffer ( $\mathrm{pH}$ 8.0) was mixed with $0.5 \mathrm{~mL}$ of enzyme solution. The mixture was incubated for $1 \mathrm{~h}$ at $60^{\circ} \mathrm{C}$ and $220 \mathrm{rpm}$. The mixture was placed on ice-cold water for $10 \mathrm{~min}$ to stop the reaction, and then centrifuged at $15,000 \mathrm{rpm}$ for $10 \mathrm{~min}$ to remove the insoluble substrates. The supernatant was evaluated for an azo dye release at $595 \mathrm{~nm}$ using SYNERGYMx 96 well micro plate reader (BioTek, USA). The control was buffer and enzyme solution treated under the same condition. One keratinase unit was defined as an amount of enzyme causing an increase in absorbance of 0.01 per hour under the standard assay protocol.

\section{Protein content quantitation}

The concentration of protein in the cell-free crude extract was quantified with the Bradford method and the standard protein was bovine serum albumin [57].

\section{Thiol group determination}

The thiol group content of the crude extract was quantitated spectrophotometrically $(412 \mathrm{~nm})$, following the measurement of yellow-colored 2-nitro-5-thiobenzoic acid (TNB) that formed upon reduction of 5,5-dithiobis-2-nitro benzoic acid (DTNB) (Sigma-Aldrich, USA), by using the method of Ellman [58]. 
Optimization of physico-chemical process conditions

The physico-chemical conditions were optimized using one variable at a time (OVAT) approach. The medium $\mathrm{pH}$ was carefully adjusted from $\mathrm{pH} 3.0$ to $\mathrm{pH} 11.0$ at interval of 1 unit in order to establish the optimal initial fermentation $\mathrm{pH}$. Likewise, incubation temperature (25$\left.40^{\circ} \mathrm{C}\right)$ and agitation speed $(0-250 \mathrm{rpm})$ were varied at intervals of $5{ }^{\circ} \mathrm{C}$ and $50 \mathrm{rpm}$, respectively. The effect of supplementation of the fermentation medium with extra sources of carbon including sucrose, soluble starch, xylose, mannitol, glucose, fructose, maltose, galactose, lactose and sorbitol (Merck chemicals (Pty) Ltd., South Africa) was evaluated at final concentration of $1.0 \mathrm{~g} / \mathrm{L}$. The concentration of carbon source with the best stimulatory effect was varied from 0.8 to 10.0 (g/L). Additionally, the effect of different concentrations of chicken feather on keratinase production was investigated by varying the medium concentration from 1.0 to 17.5 (g/L). Finally, the time course study of keratinase activity of Bacillus sp. CSK2 was implemented at the optimized conditions for $120 \mathrm{~h}$. Aliquots of the fermentation broth were periodically withdrawn ( $24 \mathrm{~h}$ interval) in an aseptic condition and used to evaluate some parameters including $\mathrm{pH}$ change, cell growth, keratinase activity, protein and thiol group concentrations.

\section{Keratinase characterization}

\section{Effect of $\mathrm{pH}$ on keratinase activity and stability}

The optimum $\mathrm{pH}$ for keratinase activity was investigated using the following buffer solutions $(0.1 \mathrm{M})$ : sodium citrate ( $\mathrm{pH} 5.0)$, potassium phosphate ( $\mathrm{pH}$ 6.0-7.0), Tris$\mathrm{HCl}$ (pH 8.0-9.0), and sodium bicarbonate- $\mathrm{NaOH}(\mathrm{pH}$ $10.0-12.0)$ at $37^{\circ} \mathrm{C}$. Also, $\mathrm{pH}$ stability of the enzyme was assessed by pre-incubating the enzyme solution with different buffer solutions (pH 6.0-9.0) for $4 \mathrm{~h}$ at $37^{\circ} \mathrm{C}$; while aliquots were periodically withdrawn ( $1 \mathrm{~h}$ interval) and used to determine the residual activity under standard assay conditions.

\section{Effect of temperature on keratinase activity and stability}

The optimal temperature for keratinase activity was determined by carrying out enzyme assay at different incubation temperatures $\left(30-80^{\circ} \mathrm{C}\right)$. Thermal stability of the keratinase was assessed by subjecting the enzyme solution to thermal pretreatment at $50{ }^{\circ} \mathrm{C}, 60^{\circ} \mathrm{C}$ and $70{ }^{\circ} \mathrm{C}$ for $120 \mathrm{~min}$. Aliquots were periodically withdrawn (30 min interval), and the residual activity was determined under optimum assay conditions.

\section{Effect of chemical agents on keratinase stability}

The effect of some chemical agents (Sigma-Aldrich, USA) including protease inhibitors $(5 \mathrm{mM})$ : phenylmethylsulfonyl fluoride (PMSF), ethylene diamine tetraacetic acid (EDTA), 1,10-phenanthroline; reducing agents $(5 \mathrm{mM})$ : sodium thioglycolate $\left(\mathrm{C}_{2} \mathrm{H}_{3} \mathrm{NaO}_{2} \mathrm{~S}\right)$, dithiothreitol (DTT), sodium sulfite $\left(\mathrm{Na}_{2} \mathrm{SO}_{3}\right)$, 2-mercaptoethanol (2-ME); oxidizing agent $(1 \% ; \mathrm{v} / \mathrm{v})$ : hydrogen peroxide $\left(\mathrm{H}_{2} \mathrm{O}_{2}\right)$; organic solvent $(1 \% ; \mathrm{v} / \mathrm{v})$ : dimethyl sulfoxide (DMSO), acetonitrile, propan-2-ol; non-ionic surfactants (1\%; v/v): triton X-100, tween-80; and anionic surfactant (5 mM): sodium dodecyl sulfate (SDS) were pre-incubated with the enzyme solution for $1 \mathrm{~h}$ at $37^{\circ} \mathrm{C}$. After that, the residual enzyme activity was determined under the standard assay protocol. The enzyme solution pre-incubated with distilled water at similar conditions served as the control and was taken as $100 \%$.

\section{Effect of metal ions on keratinase stability}

The effect of metal ions on keratinase stability was tested by pre-incubating the enzyme solution with various metal salts including $\mathrm{LiCl}, \mathrm{NaCl}, \mathrm{AgCl}, \mathrm{KCl}, \mathrm{CaCl}_{2}$, $\mathrm{MgCl}_{2}, \mathrm{MnCl}_{2}, \mathrm{ZnCl}_{2}, \mathrm{CuCl}_{2}, \mathrm{FeCl}_{2}, \mathrm{HgCl}_{2}, \mathrm{BaCl}_{2}$, $\mathrm{CoCl}_{2}, \mathrm{AlCl}_{3}$ and $\mathrm{FeCl}_{3}$ (Merck chemicals (Pty) Ltd., South Africa) at a final concentration of $5 \mathrm{mM}$ for $1 \mathrm{~h}$ at $37^{\circ} \mathrm{C}$. Residual keratinase activity was determined under the optimum enzyme assay conditions. The enzyme solution pre-incubated with distilled water served as the control and was taken as $100 \%$.

\section{Effect of solid laundry detergents on keratinase stability}

The impact of some selected commercially available laundry detergents on the crude keratinase was evaluated by following the method of Paul et al. [19]. Briefly, the solutions of solid laundry detergents which included Sunlight, Omo, Surf (Unilever, South Africa), Ariel (Procter and Gamble, South Africa) and Maq (Bliss Brands (Pty) Ltd., South Africa) were prepared with tap water to a final concentration of $7.0 \mathrm{mg} / \mathrm{mL}$. The inherent enzymes of the various detergents were inactivated by heat treatment at $100{ }^{\circ} \mathrm{C}$ for $30 \mathrm{~min}$. The enzyme solution was mixed with the preheated detergent solutions in a ratio of $4: 1$, and incubated for $60 \mathrm{~min}$ at $40{ }^{\circ} \mathrm{C}$. Thereafter, the residual keratinase activity was measured under standard assay conditions. The enzyme solution that was pretreated with tap water only served as the control and was taken as $100 \%$.

\section{Keratinase gene amplification}

The genomic DNA extraction from Bacillus sp. CSK2 was carried out following the previously described method [59]. The amplification of keratinase encoding gene was done by conventional polymerase chain reaction (PCR) using a set of oligonucleotides; kerBNK1F: TCATCTAC TGATTACGTTCC and kerBNK1R: TTAAGAAGCT TTATTTTCTTG as forward and reverse primers, respectively. The pair of primers was designed based on the nucleotide sequence of keratinase-encoding gene of $B$. thuringiensis (KX155576) available in the GenBank. This isolate is phylogenetically related to Bacillus sp. CSK2. 
The PCR was carried out using $25 \mu \mathrm{L}$ reaction mixture that consisted of $12.5 \mu \mathrm{L}$ of OneTaq ${ }^{\circ}$ Quick-Load $^{\circ} 2 \mathrm{X}$ master mix (New England Biolabs Inc., South Africa), $5.5 \mu \mathrm{L}$ of nuclease-free water, $1 \mu \mathrm{L}$ each of both forward and reverse primers and $5 \mu \mathrm{L}$ of DNA template. The target gene amplification was done by using $\mathrm{T}^{100} 0^{\mathrm{rm}}$ Thermal Cycler (Bio-Rad Laboratories Inc., Singapore), under the following cycling conditions: initial denaturation at $95^{\circ} \mathrm{C}$ for $5 \mathrm{~min}$, 35 cycles of denaturation at $95^{\circ} \mathrm{C}$ for $30 \mathrm{~s}$, annealing at $50^{\circ} \mathrm{C}$ for $1 \mathrm{~min}$, extention at $72^{\circ} \mathrm{C}$ for $1 \mathrm{~min}$, and then final extention at $72^{\circ} \mathrm{C}$ for $5 \mathrm{~min}$. The amplicons were electrophoresed on ethidium bromide stained 1.2\% agarose gel (Merck chemicals (Pty) Ltd., South Africa), and subsequently, visualized under ultraviolet transilluminator (Uvitec, UK).

\section{DNA sequencing and phylogenetic analysis}

The PCR products were analyzed using the dideoxynucleotide chain termination method [60]. Briefly, the amplified products were subjected to a post PCR clean-up using the Nucleofast 96 well post PCR clean-up plate (Macherey Nagel GmbH \& Co., Düren, Germany) on a Tecan EVO150 robotic workstation following the manufacturer's protocol. Subsequently, the purified PCR products were sequenced with the BigDye Terminator V3.1 sequencing kit (Applied Biosystems) on an ABI3730XL DNA analyzer using a $50 \mathrm{~cm}$ capillary array and POP7 (Applied Biosystems) following the protocols supplied by the manufacturer. The PCR products were sequenced bi-directionally, to obtain a reliable sequence. The nucleotide sequences were analyzed using Geneious Prime V2020.1.1 (Biomatters Ltd., Auckland, New Zealand). BLAST search was conducted to retrieve similar sequences from the National Centre for Biotechnology Information (NCBI) (https://blast.ncbi.nlm.nih.gov/Blast.cgi). The multiple amino acid sequences alignment was conducted in BioEdit [61].

\section{Statistical analysis}

Experiments were carried out in triplicates. The datasets obtained were submitted to analysis of variance and the degree of freedom was set at $P<0.05$ significance level. The analysis was conducted in Statistical Package for Social Science version 23.

\section{Supplementary Information}

The online version contains supplementary material available at https://doi. org/10.1186/s12896-020-00659-2.

Additional file 1: Figure S1. Gel picture of amplified keratinase gene from Bacillus sp. CSK2. Lane 1: DNA ladder (500 bp - 10,000 bp), lane 2: negative control, lanes 3-6: PCR amplified keratinase gene

\section{Abbreviations}

PCF: Powdered chicken feathers; BSM: Basal salt medium; DTNB: 5,5-Dithiobis-2-nitro benzoic acid; TNB: 2-Nitro-5-thiobenzoic acid;
PMSF: Phenylmethylsulfonyl fluoride; EDTA: Ethylene diamine tetraacetic acid; DMSO: Dimethyl sulfoxide; SDS: Sodium dodecyl sulfate; PCR: Polymerase chain reaction; pl: Isoelectric point; NCBI: National Centre for Biotechnology Information

\section{Acknowledgements}

The Department of Science and Innovation (DSI) and the Technology Innovation Agency (TIA) supported this work under SIIP enzyme and microbial technologies (grant number: DST/CON/0177/2018). We also acknowledge the support of the South African Medical Research Council (SAMRC).

\section{Authors' contributions}

NEN and UUN conceptualized the idea. NEN performed the experimentations, analyzed the data, and drafted the manuscript. UUN received the research grant, supervised the work and revised the manuscript. The authors read and approved the final version of the manuscript for publication.

\section{Funding}

The study was funded by the Department of Science and Innovation (DSI) and the Technology Innovation Agency (TIA) (grant number: DST/CON/0177/ 2018)

\section{Availability of data and materials}

The results of the datasets analyzed during the current study were included in the manuscript and the nucleotide sequence of Bacillus sp. CSK2 and the amplified keratinase gene was submitted to the NCBI (https://blast.ncbi.nlm. nih.gov/Blast.cgi) through the accession numbers MG215005 and MT268136, respectively. Any additional information is available from the corresponding author on reasonable request.

Ethics approval and consent to participate

Not applicable.

\section{Consent for publication}

Not applicable.

\section{Competing interests}

The authors declare that there is no conflict of interest.

Received: 4 September 2020 Accepted: 26 November 2020 Published online: 14 December 2020

\section{References}

1. Jagadeesan Y, Meenakshisundaram S, Saravanan V, Balaiah A. Sustainable production, biochemical and molecular characterization of thermo-andsolvent stable alkaline serine keratinase from novel Bacillus pumilus ar57 for promising poultry solid waste management. Int J Biol Macromol. 2020;163: 135-46 https://doi.org/10.1016/j.ijbiomac.2020.06.219.

2. Fang Z, Zhang J, Liu B, Du G, Chen J. Biochemical characterization of three keratinolytic enzymes from Stenotrophomonas maltophilia BBE11-1 for biodegrading keratin wastes. Int Biodeterior Biodegrad. 2013;82:166-72 https://doi.org/10.1016/j.ibiod.2013.03.008

3. Abdel-Fattah AM, El-Gamal MS, Ismail SA, Emran MA, Hashem AM Biodegradation of feather waste by keratinase produced from newly isolated Bacillus licheniformis ALW1. J Gene Eng Biotechnol. 2018;16:311-8 https://doi.org/10.1016/j.jgeb.2018.05.005.

4. Jaouadi B, Abdelmalek B, Fodil D, Ferradji FZ, Rekik H, Zaraî N, Bejar S. Purification and characterization of a thermostable keratinolytic serine alkaline proteinase from Streptomyces sp. strain AB1 with high stability in organic solvents. Bioresour Technol. 2010;101:8361-9 https://doi.org/10. 1016/j.biortech.2010.05.066.

5. Fontoura R, Daroit DJ, Corrêa APF, Moresco KS, Santi L, Beys-da-Silva WO, Yates JR III, Moreira JCF, Brandelli A. Characterization of a novel antioxidant peptide from feather keratin hydrolysates. New Biotechnol. 2019;49:71-6 https://doi.org/10.1016/j.nbt.2018.09.003

6. Babalola MO, Ayodeji AO, Bamidele OS, Ajele JO. Biochemica characterization of a surfactant-stable keratinase purified from Proteus vulgaris EMB-14 grown on low-cost feather meal. Biotechnol Lett. 2020:1-11 https://doi.org/10.1007/s10529-020-02976-0. 
7. Khumalo M, Tesfaye T, Sithole BB, Ramjugernath D. Possible beneficiation of waste chicken feathers via conversion into biomedical applications. Int J Chem Sci. 2019;17:298 https://doi.org/10.21767/0972-768X.1000298.

8. South African Poultry Association (SAPA). South African Poultry Association 2018 Industry Profile 2018. http://www.sapoultry.co.za/pdf-docs/sapaindustry-profile.pdf. Accessed 16 July 2020

9. Tesfaye T, Sithole B, Ramjugernath D, Chunilall V. Valorization of chicken feathers: characterization of physical properties and morphological structure. J Clean Prod. 2017;149:349-65 https://doi.org/10.1016/j.jclepro. 2017.02.112.

10. Onifade AA, Al-Sane NA, Al-Musallam AA, Al-Zarban S. A review: potentials for biotechnological applications of keratin-degrading microorganisms and their enzymes for nutritional improvement of feathers and other keratins as livestock feed resources. Bioresour Technol. 1998;66:1-11 https://doi.org/10. 1016/S0960-8524(98)00033-9.

11. Khumalo M, Sithole B, Tesfaye T. Valorization of waste chicken feathers: optimization of keratin extraction from waste chicken feathers by sodium bisulphite, sodium dodecyl sulphate and urea. J Environ Manag. 2020;262: 110329 https://doi.org/10.1016/j.jenvman.2020.110329.

12. Hassan MA, Taha TH, Hamad GM, Hashe M, Alamri S, Mostafa YS. Biochemical characterization and application of keratinase from Bacillus thuringiensis MT1 to enable valorization of hair wastes through biosynthesis of vitamin B-complex. Int J Biol Macromol. 2020a;153:561-72 https://doi.org/ 10.1016/j.jibiomac.2020.03.032.

13. De Oliveira Martinez JP, Cai G, Nachtschatt M, Navone L, Zhang Z, Robins K, Speight R. Challenges and opportunities in identifying and characterizing keratinases for value-added peptide production. Catalysts. 2020;10:184 https://doi.org/10.3390/catal10020184.

14. Srivastava B, Khatri M, Singh G, Arya SK. Microbial keratinases: an overview of biochemical characterization and its eco-friendly approach for industrial applications. J Clean Prod. 2020;252:119847 https://doi.org/10.1016/j.jclepro. 2019.119847.

15. Nnolim NE, Ntozonke N, Okoh Al, Nwodo UU. Exoproduction and characterization of a detergent-stable alkaline keratinase from Arthrobacter sp. KFS-1. Biochimie. 2020a;177:53-62 https://doi.org/10.1016/j.biochi.2020. 08.005 .

16. Nnolim NE, Okoh Al, Nwodo UU. Proteolytic bacteria isolated from agrowaste dumpsites produced keratinolytic enzymes. Biotechnol Rep. 2020b;27: e00483 https://doi.org/10.1016/j.btre.2020.e00483.

17. Yusuf I, Ahmad SA, Phang LY, Syed MA, Shamaan NA, Khalil KA, Dahalan FA, Shukor MY. Keratinase production and biodegradation of polluted secondary chicken feather wastes by a newly isolated multi heavy metal tolerant bacterium-Alcaligenes sp. AQ05-001. J Environ Manag. 2016;183: 182-95 https://doi.org/10.1016/j.jenvman.2016.08.059.

18. Tiwary E, Gupta R. Medium optimization for a novel 58 kDa dimeric keratinase from Bacillus licheniformis ER-15: biochemical characterization and application in feather degradation and dehairing of hides. Bioresour Technol. 2010;101:6103-10 https://doi.org/10.1016/j.biortech. 2010.02.090.

19. Paul T, Das A, Mandal A, Halder SK, Jana A, Maity C, Das Mohapatra PK, Pati BR, Mondal KC. An efficient cloth cleaning properties of a crude keratinase combined with detergent: towards industrial viewpoint. J Clean Prod. 2014b;66:672-84 https://doi.org/10.1016/j.jclepro.2013.10.054.

20. Kim JM, Lim WJ, Suh HJ. Feather-degrading Bacillus species from poultry waste. Process Biochem. 2001;37:287-91 https://doi.org/10.1016/500329592(01)00206-0.

21. Nnolim NE, Okoh Al, Nwodo UU. Bacillus sp. FPF-1 produced keratinase with high potential for chicken feather degradation. Molecules. 2020d;25: 1505. https://doi.org/10.3390/molecules25071505.

22. Park GT, Son HJ. Keratinolytic activity of Bacillus megaterium F7-1, a featherdegrading mesophilic bacterium. Microbiol Res. 2009;164:478-85 https://doi org/10.1016/.micres.2007.02.004.

23. Okoroma EA, Garelick H, Abiola OO, Purchase D. Identification and characterization of a Bacillus licheniformis strain with profound keratinase activity for degradation of melanized feather. Int Biodeterior Biodegrad. 2012;74:54-60 https://doi.org/10.1016/j.ibiod.2012.07.013.

24. Brandelli A, Daroit DJ, Riffel A. Biochemical features of microbial keratinases and their production and applications. Appl Microbiol Biotechnol. 2010;85: 1735-50 https://doi.org/10.1007/s00253-009-2398-5.

25. Stiborova H, Branska B, Vesela T, Lovecka P, Stranska M, Hajslova J, Jiru M, Patakova P, Demnerova K. Transformation of raw feather waste into digestible peptides and amino acids. J Chem Technol Biotechnol. 2016;91: 1629-37 https://doi.org/10.1002/jctb.4912.

26. Mohamad N, Phang LY, Abd-Aziz S. Optimization of metallo-keratinase production by Pseudomonas sp. LM19 as a potential enzyme for feather waste conversion. Biocatal Biotransform. 2017;35:41-50 https://doi.org/10. 1080/10242422.2017.1280031.

27. Reddy MR, Reddy KS, Chouhan YR, Bee H, Reddy G. Effective feather degradation and keratinase production by Bacillus pumilus GRK for its application as bio-detergent additive. Bioresour Technol. 2017;243:254-63 https://doi.org/10.1016/j.biortech.2017.06.067.

28. Gurav RG, Jadhav JP. Biodegradation of keratinous waste by Chryseobacterium sp. RBT isolated from soil contaminated with poultry waste. J Basic Microbiol. 2013;53:128-35 https://doi.org/10.1002/jobm. 201100371.

29. Nam GW, Lee DW, Lee HS, Lee J, Kim BC, Choe EA, Hwang JK, Suhartono MT, Pyun YR. Native-feather degradation by Fervidobacterium islandicum AW-1, a newly isolated keratinase-producing thermophilic anaerobe. Arch Microbiol. 2002;178:538-47 https://doi.org/10.1007/s00203-002-0489-0.

30. Ningthoujam DS, Devi LJ, Devi PJ, Kshetri P, Tamreihao K, Mukherjee S, Devi $\mathrm{S}$, Betterson N. Optimization of keratinase production by Amycolatopsis sp. strain MBRL, 40, from a limestone habitat. J bioprocess. Biotech. 2016;6:282 https://doi.org/10.4172/2155-9821.1000282.

31. Nnolim NE, Mpaka L, Okoh Al, Nwodo UU. Biochemical and molecular characterization of a thermostable alkaline metallo-keratinase from Bacillus sp. Nnolim-K1. Microorganisms. 2020c;8:1304. https://doi.org/10.3390/ microorganisms8091304.

32. Verma A, Singh H, Anwar MS, Kumar S, Ansari MW, Agrawal S. Production of thermostable organic solvent tolerant keratinolytic protease from Thermoactinomyces sp. RM4: IAA production and plant growth promotion. Front Microbiol. 2016;7:1189 https://doi.org/10.3389/fmicb.2016.01189.

33. Cai C, Zheng X. Medium optimization for keratinase production in hair substrate by a new Bacillus subtilis KD-N2 using response surface methodology. J Ind Microbiol Biotechnol. 2009;36:875-83 https://doi.org/10. 1007/s10295-009-0565-4.

34. Thankaswamy SR, Sundaramoorthy S, Palanivel S, Ramudu KN. Improved microbial degradation of animal hair waste from leather industry using Brevibacterium luteolum (MTCC 5982). J Clean Prod. 2018;189:701-8 https:// doi.org/10.1016/j.jclepro.2018.04.095.

35. Jeong JH, Lee OM, Jeon YD, Kim JD, Lee NR, Lee CY, Son HJ. Production of keratinolytic enzyme by a newly isolated feather-degrading Stenotrophomonas maltophilia that produces plant growth-promoting activity. Process Biochem. 2010a;45:1738-45 https://doi.org/10.1016/j. procbio.2010.07.020

36. Jeong JH, Park KH, Oh DJ, Hwang DY, Kim HS, Lee CY, Son HJ. Keratinolytic enzyme-mediated biodegradation of recalcitrant feather by a newly isolated Xanthomonas sp. P5. Polym Degrad Stab. 2010b;95:1969-1977.

37. He Z, Sun R, Tang Z, Bu T, Wu Q, Li C, Chen H. Biodegradation of feather waste keratin by the keratin-degrading strain Bacillus subtilis 8. J Microbiol Biotechnol. 2018;28:314-22 https://doi.org/10.4014/jmb. 1708.08077

38. Kshetri P, Ningthoujam DS. Keratinolytic activities of alkaliphilic Bacillus sp. MBRL 575 from a novel habitat, limestone deposit site in Manipur, India. SpringerPlus. 2016;5:595 https://doi.org/10.1186/s40064-016-2239-9.

39. Paul T, Das A, Mandal A, Jana A, Halder SK, Mohapatra PKD, Pati BR, Mondal KC. Smart cleaning properties of a multi tolerance keratinolytic protease from an extremophilic Bacillus tequilensis hsTKB2: prediction of enzyme modification site. Waste Biomass Valor. 2014a;5:931-45 https://doi.org/10. 1007/s12649-014-9310-y.

40. Hassan MA, Abol-Fotouh D, Omer AM, Tamer TM, Abbas E. Comprehensive insights into microbial keratinases and their implication in various biotechnological and industrial sectors: a review. Int J Biol Macromol. 2020b; 154:567-83 https://doi.org/10.1016/j.jijbiomac.2020.03.116.

41. Gupta S, Nigam A, Singh R. Purification and characterization of a Bacillus subtilis keratinase and its prospective application in feed industry. Acta Biol Szeged. 2015;59:197-204.

42. Pawar VA, Prajapati AS, Akhani RC, Patel DH, Subramanian RB. Molecular and biochemical characterization of a thermostable keratinase from Bacillus altitudinis RBDV1. 3. Biotech. 2018:8:107 https://doi.org/10.1007/s13205-0181130-5.

43. Fakhfakh N, Kanoun S, Manni L, Nasri M. Production and biochemical and molecular characterization of a keratinolytic serine protease from chicken 
feather-degrading Bacillus licheniformis RPk. Can J Microbiol. 2009;55:42736 https://doi.org/10.1139/W08-143.

44. Prakash P, Jayalakshmi SK, Sreeramulu K. Purification and characterization of extreme alkaline, thermostable keratinase, and keratin disulfide reductase produced by Bacillus halodurans PPKS-2. Appl Microbiol Biotechnol. 2010;87: 625-33 https://doi.org/10.1007/s00253-010-2499-1.

45. Fakhfakh-Zouari N, Hmidet N, Haddar A, Kanoun S, Nasri M. A novel serine metallokeratinase from a newly isolated Bacillus pumilus A1 grown on chicken feather meal: biochemical and molecular characterization. Appl Biochem Biotechnol. 2010;162:329-44 https://doi.org/10.1007/s12010-009-8774-x.

46. Gegeckas A, Šimkutè A, Gudiukaitè R, Čitavičius DJ. Characterization and application of keratinolytic paptidases from Bacillus spp. Int J Biol Macromol. 2018;113:1206-13 https://doi.org/10.1016/j.jibiomac.2018.03.046.

47. Thys RCS, Brandelli A. Purification and properties of a keratinolytic metalloprotease from microbacterium sp. J Appl Microbiol. 2006;101:125968 https://doi.org/10.1111/j.1365-2672.2006.03050.x.

48. Wang SL, Hsu WT, Liang TW, Yen YH, Wang CL. Purification and characterization of three novel keratinolytic metalloproteases produced by Chryseobacterium indologenes TKU014 in a shrimp shell powder medium. Bioresour Technol. 2008;99:5679-86 https://doi.org/10.1016/j.biortech.2007. 10.024 .

49. Zhang RX, Gong JS, Zhang DD, Su C, Hou YS, Li H, Shi JS, Xu ZH. A metallokeratinase from a newly isolated Acinetobacter sp. R-1 with low collagenase activity and its biotechnological application potential in leather industry. Bioprocess Biosyst Eng. 2016;39:193-204 https://doi.org/10.1007/s00449-0151503-7.

50. Riffel A, Lucas F, Heeb P, Brandelli A. Characterization of a new keratinolytic bacterium that completely degrades native feather keratin. Arch Microbiol. 2003;179:258-65 https://doi.org/10.1007/s00203-003-0525-8.

51. Thys RCS, Lucas FS, Riffel A, Heeb P, Brandelli A. Characterization of a protease of a feather-degrading microbacterium species. Lett Appl Microbiol. 2004;39:181-6 https://doi.org/10.1111/j.1472-765X.2004.01558.x.

52. Rai SK, Mukherjee AK. Optimization of production of an oxidant and detergentstable alkaline $\beta$-keratinase from Brevibacillus sp. strain AS-S10-ll: application of enzyme in laundry detergent formulations and in leather industry. Biochem Eng J. 2011;54:47-56 https://doi.org/10.1016/.bej.2011.01.007.

53. Cai CG, Chen JS, Qi JJ, Yin Y, Zheng XD. Purification and characterization of keratinase from a new Bacillus subtilis strain. J Zhejiang Univ Sci B. 2008;9: 713-20 https://doi.org/10.1631/jzus.B0820128.

54. Wade RC, Gabdoulline RR, Lüdemann SK, Lounnas V. Electrostatic steering and ionic tethering in enzyme-ligand binding: insights from simulations. Proc Natl Acad Sci. 1998;95:5942-9 https://doi.org/10.1073/pnas.95.11.5942.

55. Dorra G, Ines K, Imen BS, Laurent C, Sana A, Olfa T, Pascal C, Thierry J, Ferid L. Purification and characterization of a novel high molecular weight alkaline protease produced by an endophytic Bacillus halotolerans strain CT2. Int J Biol Macromol. 2018;111:342-51 https://doi.org/10.1016/j.jjbiomac. 2018.01.024.

56. Rekik H, Jaouadi NZ, Gargouri F, Bejar W, Frikha F, Jmal N, Bejar S, Jaouadi B. Production, purification and biochemical characterization of a novel detergent-stable serine alkaline protease from Bacillus safensis strain RH12. Int J Biol Macromol. 2019;121:1227-39 https://doi.org/10.1016/j.jjbiomac. 2018.10.139

57. Bradford MM. A rapid and sensitive method for the quantitation of microgram quantities of protein utilizing the principle of protein-dye binding. Anal Biochem. 1976;72:248-54 https://doi.org/10.1016/00032697(76)90527-3.

58. Ellman GL. Tissue sulfhydryl groups. Arch Biochem Biophys. 1959;82:70-7.

59. Maugeri TL, Carbone M, Fera MT, Gugliandolo C. Detection and differentiation of Vibrio vulnificus in seawater and plankton of a coastal zone of the Mediterranean Sea. Res Microbiol. 2006;157:194-200 https://doi. org/10.1016/.jesmic.2005.06.007.

60. Sanger F, Nicklen S, Coulson AR. DNA sequencing with chain-terminating inhibitors. Proc Natl Acad Sci. 1977;74:5463-7.

61. Thompson JD, Higgins DG, Gibson TJ. CLUSTAL W: improving the sensitivity of progressive multiple sequence alignment through sequence weighting, position-specific gap penalties and weight matrix choice. Nucleic Acids Res. 1994;22:4673-80 https://doi.org/10.1093/nar/22.22.4673.

\section{Publisher's Note}

Springer Nature remains neutral with regard to jurisdictional claims in published maps and institutional affiliations.

Ready to submit your research? Choose BMC and benefit from:

- fast, convenient online submission

- thorough peer review by experienced researchers in your field

- rapid publication on acceptance

- support for research data, including large and complex data types

- gold Open Access which fosters wider collaboration and increased citations

- maximum visibility for your research: over $100 \mathrm{M}$ website views per year

At BMC, research is always in progress.

Learn more biomedcentral.com/submissions 